Article

\title{
Synthesis and Structure of Methylsulfanyl Derivatives of Nickel Bis(Dicarbollide) ${ }^{\dagger}$
}

\author{
Sergey A. Anufriev ${ }^{1}$, Kyrill Yu. Suponitsky ${ }^{1}\left(\mathbb{D}\right.$, Oleg A. Filippov $\left.{ }^{1,2} \mathbb{(}\right)$ and Igor B. Sivaev ${ }^{1,3, *}$ \\ 1 A.N. Nesmeyanov Institute of Organoelement Compounds, Russian Academy of Sciences, 28 Vavilov Str., \\ Moscow 119991, Russia; trueman476@mail.ru (S.A.A.); kirshik@yahoo.com (K.Y.S.); \\ h-bond@ineos.ac.ru (O.A.F.) \\ 2 Shemyakin-Ovchinnikov Institute of Bioorganic Chemistry, Russian Academy of Sciences, \\ 16/10 Miklukho-Maklay Str., Moscow 117997, Russia \\ 3 Basic Department of Chemistry of Innovative Materials and Technologies, G.V. \\ Plekhanov Russian University of Economics, 36 Stremyannyi Line, Moscow 117997, Russia \\ * Correspondence: sivaev@ineos.ac.ru; Tel.: +7-916-590-2025 \\ + Dedicated to Professor Bohumil Štibr in the recognition of his outstanding contribution in the carborane \\ chemistry and with very best wishes on the occasion of his $80^{\text {th }}$ birthday.
}

Academic Editors: Igor B. Sivaev, Narayan S. Hosmane and Bohumír Grüner Received: 16 November 2019; Accepted: 2 December 2019; Published: 4 December 2019

\begin{abstract}
Symmetrically and unsymmetrically substituted methylsulfanyl derivatives of nickel(III) bis(dicarbollide) $\left(\mathrm{Bu}_{4} \mathrm{~N}\right)\left[8,8^{\prime}-(\mathrm{MeS})_{2}-3,3^{\prime}-\mathrm{Ni}\left(1,2-\mathrm{C}_{2} \mathrm{~B}_{9} \mathrm{H}_{10}\right)_{2}\right],\left(\mathrm{Bu}_{4} \mathrm{~N}\right)\left[4,4^{\prime}-(\mathrm{MeS})_{2}-3,3^{\prime}-\mathrm{Ni}\left(1,2-\mathrm{C}_{2} \mathrm{~B}_{9} \mathrm{H}_{10}\right)_{2}\right]$, and $\left(\mathrm{Bu}_{4} \mathrm{~N}\right)\left[4,7^{\prime}-(\mathrm{MeS})_{2}-3,3^{\prime}-\mathrm{Ni}\left(1,2-\mathrm{C}_{2} \mathrm{~B}_{9} \mathrm{H}_{10}\right)_{2}\right]$ were synthesized, starting from [Ni(acac $\left.)_{2}\right]_{3}$ and the corresponding methylsulfanyl derivatives of nido-carborane $\left(\mathrm{Bu}_{4} \mathrm{~N}\right)\left[10-\mathrm{MeS}-7,8-\mathrm{C}_{2} \mathrm{~B}_{9} \mathrm{H}_{11}\right]$ and $\left(\mathrm{Bu}_{4} \mathrm{~N}\right)\left[10-\mathrm{MeS}-7,8-\mathrm{C}_{2} \mathrm{~B}_{9} \mathrm{H}_{11}\right]$. Structures of the synthesized metallacarboranes were studied by single-crystal $\mathrm{X}$-ray diffraction and quantum chemical calculations. The symmetrically substituted 8, $8^{\prime}$-isomer adopts transoid conformation stabilized by two pairs of intramolecular C-H..S hydrogen bonds between the dicarbollide ligands. The unsymmetrically substituted $4,7^{\prime}$-isomer adopts gauche conformation, which is stabilized by two nonequivalent $\mathrm{C}-\mathrm{H} \cdots \mathrm{S}$ hydrogen bonds and one short chalcogen $\mathrm{B}-\mathrm{H} \cdots \mathrm{S}$ bond $(2.53 \AA,-1.4 \mathrm{kcal} / \mathrm{mol})$. The gauche conformation was found to be also preferred for the $4,7^{\prime}$-isomer.
\end{abstract}

Keywords: metallacarboranes; nickel bis(dicarbollide); SMe derivatives; synthesis; structure; hydrogen bonds; chalcogen bonds

\section{Introduction}

Molecular switches are molecules or supramolecular assemblies that can exist in two or more stable states that differ in the mutual orientation of the components and which can be transformed from one state to another by means of various external stimuli via rotation of these components relative to each other [1]. Molecular switches are the basic structural elements of any molecular electronic devices, in particular, molecular logic gates, which are capable of performing all the simplest logical and arithmetic operations, such as s summation and subtraction, encoding and decoding functions, and so on [2-6].

Fifteen years ago, nickel bis(dicarbollides) $\left[3,3^{\prime}-\mathrm{Ni}\left(1,2-\mathrm{C}_{2} \mathrm{~B}_{9} \mathrm{H}_{11}\right)_{2}\right]^{-1 / 0}$ were proposed as the main construction element of molecular switches in which switching between two stable forms is achieved by reversible change of the nickel oxidation degree $[7,8]$. The cisoid conformation with the dicarbollide ligands turned by $\sim 36$ degree relative each other rotation angle is most favorable for the nickel(IV) bis(dicarbollide) complex, whereas the transoid conformation with ligand rotation angle 180 degree is preferred for nickel(III) bis(dicarbollide) [7-10]. Somewhat later, several such molecular switches were 
synthesized [11,12]; however, it was found that the difference in energies between the transoid and gauche rotamers in the synthesized nickel(III) complexes are negligibly low $(\sim 0.1 \mathrm{kcal} / \mathrm{mol})$ [11]. In addition, it was found that nickel(IV) bis(dicarbollide) complexes are unstable in a number of solvents and are easily reduced to the corresponding nickel(III) complexes $[13,14]$. Thus, nickel bis(dicarbollide) complexes cannot be used to create effective electrochemically controlled molecular switches.

An alternative option involves the use of transition metal bis(dicarbollide) derivatives as structural elements in design of the complexation-driven molecular switches [15]. Additional stabilization of certain rotamers can be achieved by an introduction of appropriate substituents in the upper belt of the dicarbollide ligand, which results in the appearance of stabilizing interactions between the ligands. For instance, the introduction of iodine atoms to positions 8 and $8^{\prime}$ of the cobalt bis(dicarbollide) anion increases the energy difference between the transoid and gauche and the transoid and cisoid rotamers of $\left[8,8^{\prime}-\mathrm{I}_{2}-3,3^{\prime}-\mathrm{Co}\left(1,2-\mathrm{C}_{2} \mathrm{~B}_{9} \mathrm{H}_{10}\right)_{2}\right]^{-}$in comparison with the parent anion from 0.4 to $4.7 \mathrm{kcal} / \mathrm{mol}$ and from 2.5 to $15.7 \mathrm{kcal} / \mathrm{mol}$, respectively, due to intramolecular C-H $\cdots \mathrm{I}-\mathrm{B}$ hydrogen bonding between the ligands $[16,17]$. The bistability of molecular switches can be achieved by using substituents that are capable to form weak intramolecular hydrogen bonds between the dicarbollide ligands in the transoid conformation and stronger dative bonds with external transition metals in the cisoid conformation. Indeed, we found that the methylsulfanyl groups are able to stabilize the transoid conformation of the corresponding derivatives of cobalt and iron bis(dicarbollides) $\left[8,8^{\prime}-(\mathrm{MeS})_{2}-3,3^{\prime}-\mathrm{M}\left(1,2-\mathrm{C}_{2} \mathrm{~B}_{9} \mathrm{H}_{10}\right)_{2}\right]^{-}$ $(\mathrm{M}=\mathrm{Co}, \mathrm{Fe})$ due to formation of intramolecular C-H..S(Me)B hydrogen bonds [18,19]. On the other hand, in the presence of external transition metals or labile metal complexes, the methylsulfanyl groups form complexes with them, resulting in transformation of the transoid conformation of cobalt bis(dicarbollide) to the cisoid one $[20,21]$.

In this contribution, we describe the synthesis and structure of the methylsulfanyl derivatives of nickel bis(dicarbollide).

\section{Results and Discussion}

\subsection{Synthesis}

Our attempts to prepare 8,8'-di(methylsulfanyl) derivative of nickel(III) bis(dicarbollide) $\left[8,8^{\prime}-(\mathrm{MeS})_{2}-3,3^{\prime}-\mathrm{Ni}\left(1,2-\mathrm{C}_{2} \mathrm{~B}_{9} \mathrm{H}_{10}\right)_{2}\right]^{-}$in aqueous solution $[22,23]$ by the reaction of $\mathrm{NiCl}_{2} \bullet 6 \mathrm{H}_{2} \mathrm{O}$ with [10-MeS-7,8- $\left.\mathrm{C}_{2} \mathrm{~B}_{9} \mathrm{H}_{11}\right]^{-}$in $40 \%$ aqueous $\mathrm{NaOH}$, as well as in nonaqueous media, using anhydrous $\mathrm{NiCl}_{2}$ in tetrahydrofuran $[13,22]$, were unsuccessful. Nevertheless, we were able to synthesize the goal product by using the same approach that was used previously for the synthesis of $6,6^{\prime}$-substituted derivatives of nickel bis(dicarbollide) [11,12,24], namely the reaction of nickel(II) acetylacetonate complex $\left[\mathrm{Ni}_{3}(\mathrm{acac})_{6}\right]$ with $\left(\mathrm{Bu}_{4} \mathrm{~N}\right)\left[10-\mathrm{MeS}-7,8-\mathrm{C}_{2} \mathrm{~B}_{9} \mathrm{H}_{11}\right]$ in tetrahydrofuran in the presence of $t$-BuOK (Scheme 1).

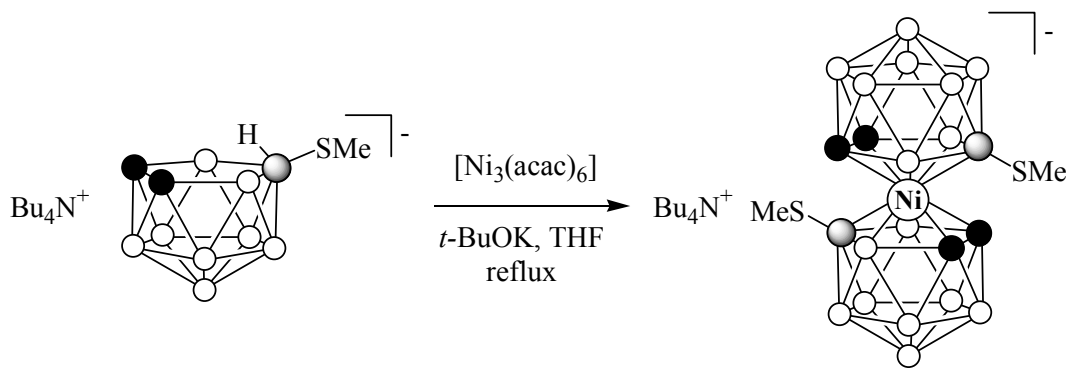

Scheme 1. Synthesis of $\left[8,8^{\prime}-(\mathrm{MeS})_{2}-3,3^{\prime}-\mathrm{Ni}\left(1,2-\mathrm{C}_{2} \mathrm{~B}_{9} \mathrm{H}_{10}\right)_{2}\right]^{-}$.

The similar reaction of $\left[\mathrm{Ni}_{3}(\mathrm{acac})_{6}\right]$ with unsymmetrically substituted methylsulfanyl derivative of nido-carborane $\left(\mathrm{Bu}_{4} \mathrm{~N}\right)\left[9-\mathrm{MeS}-7,8-\mathrm{C}_{2} \mathrm{~B}_{9} \mathrm{H}_{11}\right]$ results in the mixture of rac- $\left(\mathrm{Bu}_{4} \mathrm{~N}\right)\left[4,4^{\prime}-(\mathrm{MeS})_{2}-3,3^{\prime}-\right.$ $\left.\mathrm{Ni}\left(1,2-\mathrm{C}_{2} \mathrm{~B}_{9} \mathrm{H}_{10}\right)_{2}\right]$ and meso- $\left(\mathrm{Bu}_{4} \mathrm{~N}\right)\left[4,7^{\prime}-(\mathrm{MeS})_{2}-3,3^{\prime}-\mathrm{Ni}\left(1,2-\mathrm{C}_{2} \mathrm{~B}_{9} \mathrm{H}_{10}\right)_{2}\right]$ (Scheme 2). 


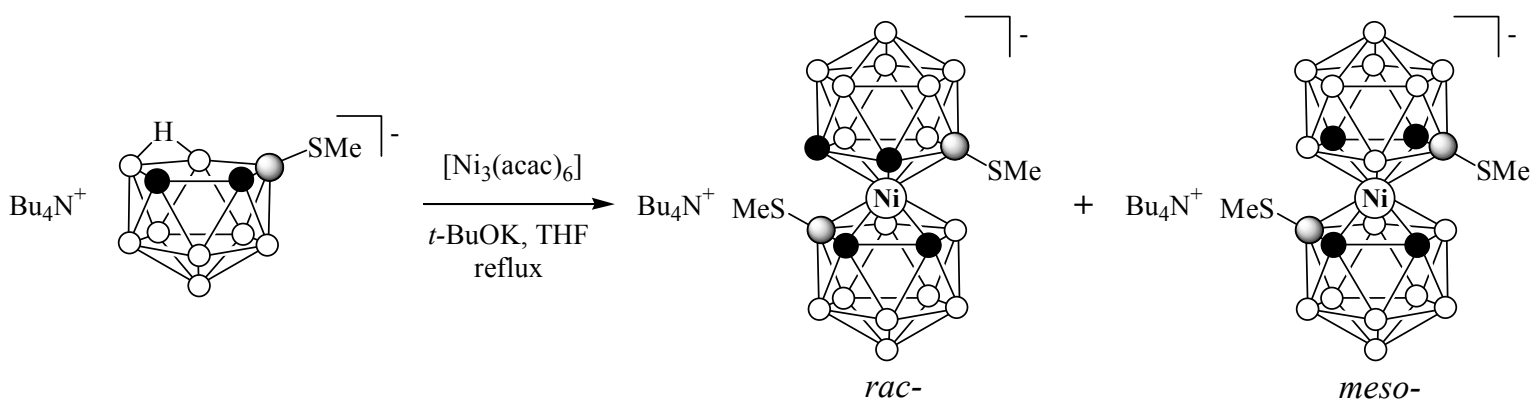

Scheme 2. Synthesis of $\left[4,4^{\prime}-(\mathrm{MeS})_{2}-3,3^{\prime}-\mathrm{Ni}\left(1,2-\mathrm{C}_{2} \mathrm{~B}_{9} \mathrm{H}_{10}\right)_{2}\right]^{-}$and $\left[4,7^{\prime}-(\mathrm{MeS})_{2}-3,3^{\prime}-\mathrm{Ni}\left(1,2-\mathrm{C}_{2} \mathrm{~B}_{9} \mathrm{H}_{10}\right)_{2}\right]^{-}$.

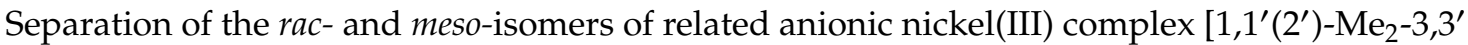
$\left.-\mathrm{Ni}\left(1,2-\mathrm{C}_{2} \mathrm{~B}_{9} \mathrm{H}_{10}\right)_{2}\right]^{-}$by their oxidation to the corresponding neutral nickel(IV) complexes has been described in the literature [25]. However, it was found that attempts to oxidize both diastereomeric $\left(\mathrm{Bu}_{4} \mathrm{~N}\right)\left[4,4^{\prime}\left(7^{\prime}\right)-(\mathrm{MeS})_{2}-3,3^{\prime}-\mathrm{Ni}\left(1,2-\mathrm{C}_{2} \mathrm{~B}_{9} \mathrm{H}_{10}\right)_{2}\right]$ and symmetrically substituted $\left(\mathrm{Bu}_{4} \mathrm{~N}\right)\left[8,8^{\prime}-(\mathrm{MeS})_{2}-3,3^{\prime}-\mathrm{Ni}\left(1,2-\mathrm{C}_{2} \mathrm{~B}_{9} \mathrm{H}_{10}\right)_{2}\right]$ nickel(III) complexes to the corresponding nickel(IV) complexes with iron chloride in acetonitrile lead to their decomposition. Therefore, by analogy with the corresponding derivatives of cobalt bis(dicarbollide) [18], column chromatography was used to separate the nickel(III) diastereomeric complexes. The ${ }^{11} \mathrm{~B}$ NMR spectra of all the obtained paramagnetic complexes (Figures S1-S3) are quite characteristic; however, unlike the similar derivatives of paramagnetic iron bis(dicarbollide) $[19,26,27]$, their interpretation is not possible. Therefore, an $\mathrm{X}$-ray diffraction study is crucial to determine the structure of the diastereomers.

\subsection{X-Ray Diffraction Study}

Since the chemistry of nickel bis(dicarbollides) is much less studied than the chemistry of its iron and cobalt analogues, only a limited number of X-ray structures of its derivatives are known. Like the parent nickel bis(dicarbollide), its derivatives contain substituents in the lower belt of the dicarbollide ligand adopt transoid conformation in the nickel(III) complexes and cisoid conformation in the nickel(IV) complexes $[8,11,23]$. In the case of derivatives containing substituents in the upper belt of the ligand, the structure of the complexes depends not only on the oxidation state of the metal, but also on the type and position of the substituents. The transoid conformation was found both in $1,1^{\prime}-\mathrm{Me}_{2}$ - and 1,2'-Me ${ }_{2}$-derivatives of nickel(IV) bis(dicarbollide), whereas the corresponding nickel(III) complexes adopt gauche and transoid conformations, respectively [25]. The gauche conformation stabilized by two intramolecular $\mathrm{C}-\mathrm{H} \cdots \mathrm{OMe}$ hydrogen bonds was found in the $8,8^{\prime}$-(MeO) $)_{2}$-derivative of nickel(IV) bis(dicarbollide) [28]. The same conformation stabilized by two intramolecular C- $\mathrm{H} \cdots \mathrm{SMe}_{2}$ bonds was found also in the $8,8^{\prime}$-( $\left.\mathrm{Me}_{2} \mathrm{~S}\right)_{2}$-derivative of nickel(II) bis(dicarbollide) [29]. The latter examples demonstrate the role of substituents capable of forming intramolecular hydrogen bonds in the stabilization of rotamers, which are generally less preferred in the absence of such substituents.

Single-crystal X-ray diffraction study of $\left(\mathrm{Bu}_{4} \mathrm{~N}\right)\left[8,8^{\prime}-(\mathrm{MeS})_{2}-3,3^{\prime}-\mathrm{Ni}\left(1,2-\mathrm{C}_{2} \mathrm{~B}_{9} \mathrm{H}_{10}\right)_{2}\right]$ demonstrated that, similarly to the corresponding derivatives of iron(II) and cobalt(III) bis(dicarbollides) $[18,19]$, the dicarbollide ligands in the symmetrically substituted anion $\left[8,8^{\prime}-(\mathrm{MeS})_{2}-3,3^{\prime}-\mathrm{Ni}\left(1,2-\mathrm{C}_{2} \mathrm{~B}_{9} \mathrm{H}_{10}\right)_{2}\right]^{-}$ adopt transoid configuration stabilized by four (two pairs) intramolecular $\mathrm{CH} \cdots \mathrm{S}$ contacts $(2.78-2.83 \AA$ ) between the dicarbollide ligands (Figure 1).

An asymmetric unit cell contains three structural units: one cation and two halves of anion (A and $\mathrm{A}^{\prime}$ ). The crystal structure is formed by alternate layers parallel to the $b c$ crystallographic plane (Figure S4). Most of intermolecular interactions between different structural units are of van-der-Waals-type. However, it is interesting to note that, in anionic layers, interactions between $\mathrm{A}$ and $\mathrm{A}^{\prime}$ are somewhat more pronounced (Figure 2), and that might be the reason of formation of two independent anions. Such conclusion can be supported by many literature examples in which interactions between different structural units appear to be stronger [30-32]. 


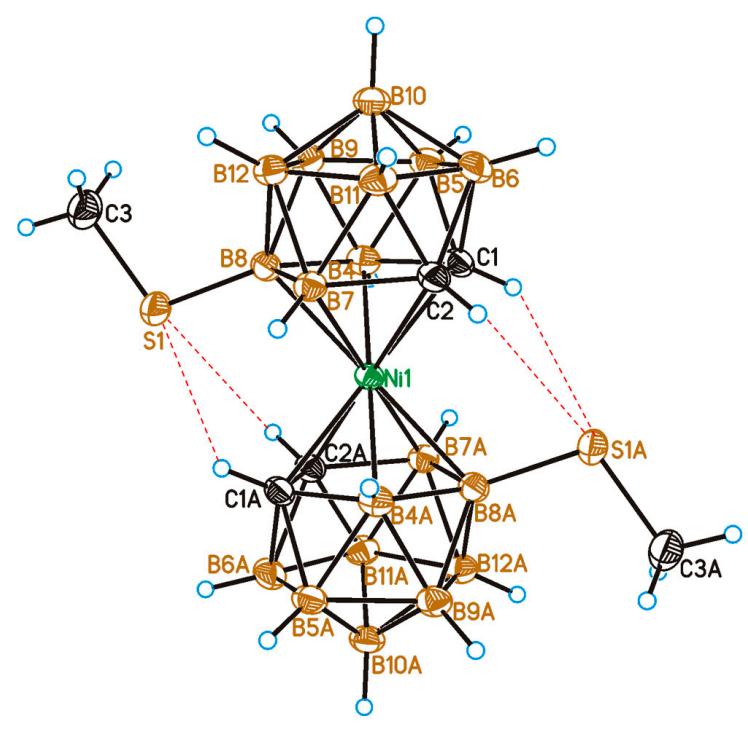

Figure 1. Thermal ellipsoid plot (50\%) and labeling scheme for $\left[8,8^{\prime}-(\mathrm{MeS})_{2}-3,3^{\prime}-\mathrm{Ni}\left(1,2-\mathrm{C}_{2} \mathrm{~B}_{9} \mathrm{H}_{10}\right)_{2}\right]^{-}$.

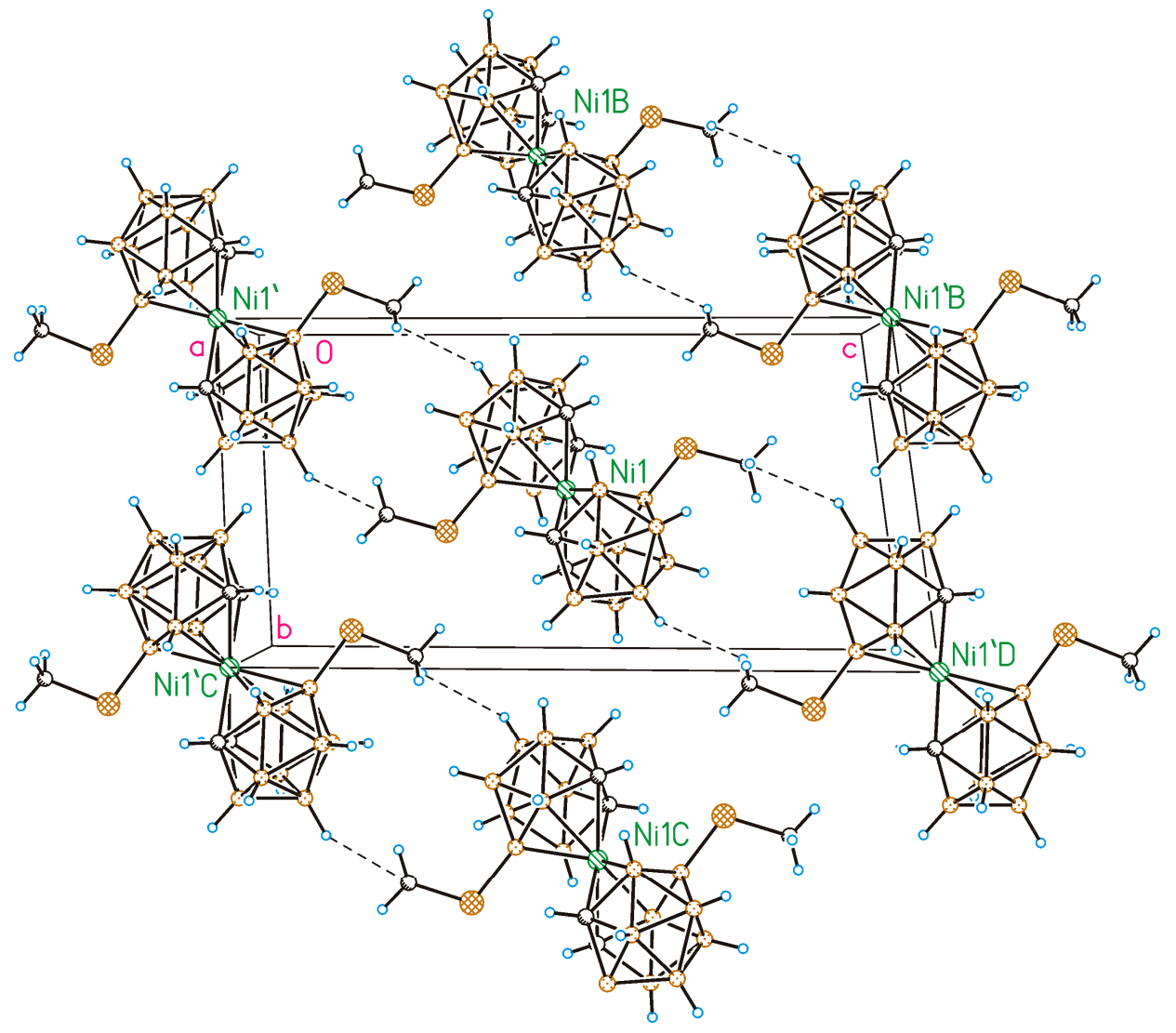

Figure 2. The structure of anionic layer. The shortest $\mathrm{H} \cdots \mathrm{H}$ contacts $\left(\mathrm{BH}(10) \cdots \mathrm{H}_{3} \mathrm{C}\right.$ of $\left.2.58 \AA\right)$ are observed between A and A' anions. Each anion is surrounded by only two anions of the same type and by four anions of the different type.

Single-crystal X-ray diffraction study of the tetrabutylammonium salt of the meso-diastereomer $\left(\mathrm{Bu}_{4} \mathrm{~N}\right)\left[4,7^{\prime}-(\mathrm{MeS})_{2}-3,3^{\prime}-\mathrm{Ni}\left(1,2-\mathrm{C}_{2} \mathrm{~B}_{9} \mathrm{H}_{10}\right)_{2}\right]$ revealed that it is isostructural with the corresponding iron [19] and cobalt [18] complexes. Similarly to the corresponding derivatives of iron(III) and cobalt(III) bis(dicarbollides), the dicarbollide ligands in the $\left[4,7^{\prime}-(\mathrm{MeS})_{2}-3,3^{\prime}-\mathrm{Ni}\left(1,2-\mathrm{C}_{2} \mathrm{~B}_{9} \mathrm{H}_{10}\right)_{2}\right]^{-}$anion adopt gauche configuration stabilized by two $\mathrm{CH} \cdots \mathrm{S}$ and one $\mathrm{BH} \cdots \mathrm{S}$ intramolecular contacts (Figure 3). 


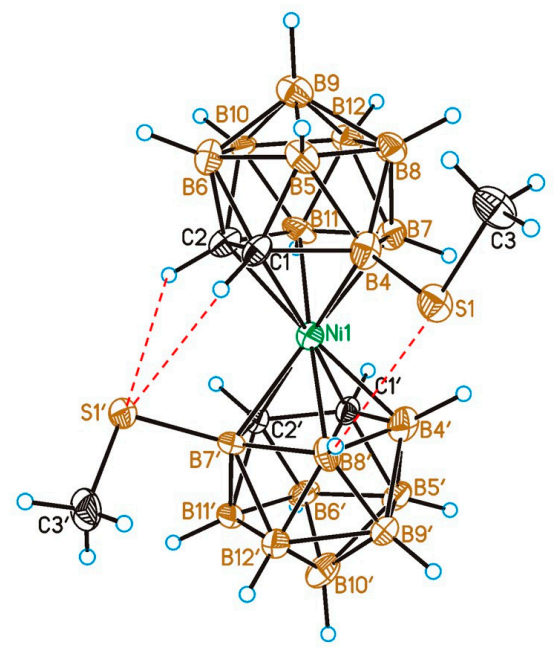

Figure 3. Thermal ellipsoid plot (50\%) and labeling scheme for $\left[4,7^{\prime}-(\mathrm{MeS})_{2}-3,3^{\prime}-\mathrm{Ni}\left(1,2-\mathrm{C}_{2} \mathrm{~B}_{9} \mathrm{H}_{10}\right)_{2}\right]^{-}$.

An asymmetric unit cell consists of one cation and one anion. Crystal packing of $\left(\mathrm{Bu}_{4} \mathrm{~N}\right)\left[4,7^{\prime}-(\mathrm{MeS})_{2}-3,3^{\prime}-\mathrm{Ni}\left(1,2-\mathrm{C}_{2} \mathrm{~B}_{9} \mathrm{H}_{10}\right)_{2}\right]$ is also built up of alternate cationic and anionic layers (Figure S5). However, in contrast to $\left(\mathrm{Bu}_{4} \mathrm{~N}\right)\left[8,8^{\prime}-(\mathrm{MeS})_{2}-3,3^{\prime}-\mathrm{Ni}\left(1,2-\mathrm{C}_{2} \mathrm{~B}_{9} \mathrm{H}_{10}\right)_{2}\right]$, layers in $\left(\mathrm{Bu}_{4} \mathrm{~N}\right)\left[4,7^{\prime}-(\mathrm{MeS})_{2}-3,3^{\prime}-\mathrm{Ni}\left(1,2-\mathrm{C}_{2} \mathrm{~B}_{9} \mathrm{H}_{10}\right)_{2}\right]$ adopt corrugated shape, and cationic layers penetrate into anionic ones. Also, in contrast to $\left(\mathrm{Bu}_{4} \mathrm{~N}\right)\left[8,8^{\prime}-(\mathrm{MeS})_{2}-3,3^{\prime}-\mathrm{Ni}\left(1,2-\mathrm{C}_{2} \mathrm{~B}_{9} \mathrm{H}_{10}\right)_{2}\right]$, stabilization of anionic layers in $\left(\mathrm{Bu}_{4} \mathrm{~N}\right)\left[4,7^{\prime}-(\mathrm{MeS})_{2}-3,3^{\prime}-\mathrm{Ni}\left(1,2-\mathrm{C}_{2} \mathrm{~B}_{9} \mathrm{H}_{10}\right)_{2}\right]$ is provided by significant contribution of weak $\mathrm{C}_{\mathrm{carb}}-\mathrm{H} \cdots \mathrm{S}$ hydrogen bonds (Figure 4 ).

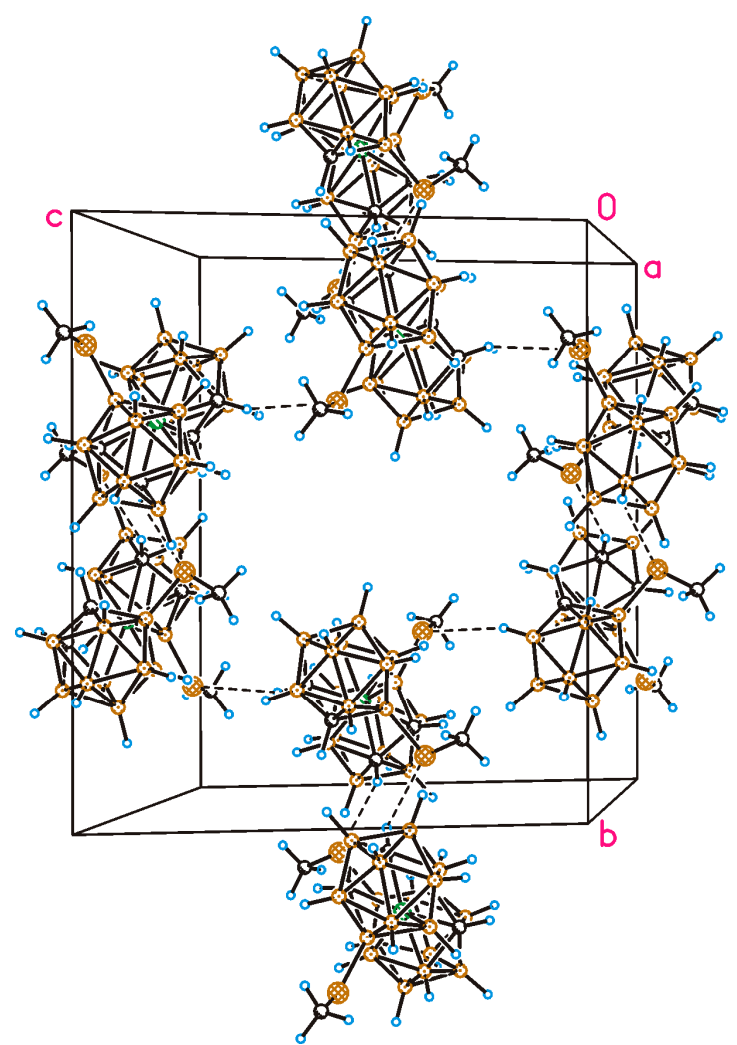

Figure 4. The structure of anionic layer stabilized by weak $\mathrm{C1}^{\prime}-\mathrm{H} 1 \cdots \mathrm{S} 1$ (C-H is $1.12 \AA, \mathrm{C} \cdots \mathrm{S}$ is $3.944(12)$ $\AA, H \cdots S$ is $2.89 \AA,<C H S$ is $\left.158^{\circ}\right)$ and $C 2-H 2 \cdots S 1^{\prime}(C-H$ is $1.12 \AA, C \cdots S$ is $3.732(13) \AA, H \cdots S$ is $2.77 \AA$, $<\mathrm{CHS}$ is $144^{\circ}$ ) hydrogen bonds. 
Despite that 4,7'-bis(methylsulfanyl) derivatives of iron, cobalt, and nickel bis(dicarbollides) are isostructural, a thorough analysis of the structural features of these complexes (Table 1) revealed that, despite the largest size of the nickel cation [33] that clearly reflects at the metal $\cdots$ dicarbollide ligand distance, the $\mathrm{BH} \cdots \mathrm{S}$ chalcogen bond in the nickel complex is much shorter $(2.53 \AA)$ than in other complexes (2.61 and $2.70 \AA$ for the iron and cobalt complexes, respectively) and probably plays a larger role in stabilization of the gauche conformation.

Table 1. Some X-ray structure parameters of $\left[4,7^{\prime}-(\mathrm{MeS})_{2}-3,3^{\prime}-\mathrm{M}\left(1,2-\mathrm{C}_{2} \mathrm{~B}_{9} \mathrm{H}_{10}\right)_{2}\right]^{-}(\mathrm{M}=\mathrm{Fe}, \mathrm{Co}$, $\mathrm{Ni}$ ) anions.

\begin{tabular}{|c|c|c|c|}
\hline & $\mathbf{M}=\mathbf{F e}$ & $\mathbf{M}=\mathbf{C o}$ & $\mathrm{M}=\mathrm{Ni}$ \\
\hline $\mathrm{C}(1) \mathrm{H}(1) \cdots \mathrm{S}\left(1^{\prime}\right)$ distance, $\AA$ & 2.75 & $2.71(3)$ & 2.68 \\
\hline $\mathrm{C}(2) \mathrm{H}(2) \cdots \mathrm{S}\left(1^{\prime}\right)$ distance, $\AA$ & 2.69 & $2.70(3)$ & 2.83 \\
\hline $\mathrm{S}\left(1^{\prime}\right) \mathrm{Me}$ group rotation angle, ${ }^{\circ}$ & $27.9(2)$ & $29.59(14)$ & $30.1(9)$ \\
\hline 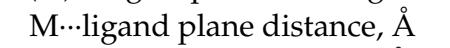 & $1.530(3)$ & $1.474(2)$ & $1.555(10)$ \\
\hline $\mathrm{B}\left(8^{\prime}\right) \mathrm{H}\left(8^{\prime}\right) \cdots \mathrm{S}(1)$ distance, $\AA$ & 2.61 & $2.70(3)$ & 2.53 \\
\hline $\mathrm{S}(1)$ Me group rotation angle, ${ }^{\circ}$ & $6.5(2)$ & $6.66(13)$ & $10.9(9)$ \\
\hline 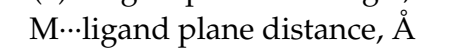 & $1.538(2)$ & $1.482(2)$ & $1.582(9)$ \\
\hline ligand rotation angle, ${ }^{\circ}$ & $102.4(3)$ & 104.2(2) & $105.0(11)$ \\
\hline
\end{tabular}

Generally, the formation of a chalcogen bond is explained in terms of the positive electrostatic potential present on the outermost portion of the chalcogen's surface, opposite to the R-Ch bonds. This region of positive electrostatic potential, which is called the " $\sigma$-hole", can interact attractively with negative sites of the same molecule or other molecules. Due to the presence of lone pairs of the chalcogen atom, a $\sigma$-hole is usually surrounded by a region of negative molecular electrostatic potential, and this determines a high directionality of the chalcogen bonds [34-36]. The acceptors of the chalcogen bond may be atoms with an unshared electron pair (e.g., pyridine or amine nitrogen atom, and ether or carbonyl group oxygen atom), $\pi$-system (e.g., double or triple bond and arene moiety), or anion (e.g., halide anion and polyatomic oxyanion) [37]. To the best of our knowledge, there is only one reference in the literature to boron hydrides as acceptors of chalcogen bonds [38], and examples of chalcogen bonds with other hydrides are quite rare, as well $[39,40]$.

Therefore, in order to assess the contribution of various factors to the stabilization of the gauche conformation of the meso-diastereomer $\left[4,7^{\prime}-(\mathrm{MeS})_{2}-3,3^{\prime}-\mathrm{Ni}\left(1,2-\mathrm{C}_{2} \mathrm{~B}_{9} \mathrm{H}_{10}\right)_{2}\right]^{-}$, as well as to obtain information on the structure of the rac-diastereomer $\left[4,4^{\prime}-(\mathrm{MeS})_{2}-3,3^{\prime}-\mathrm{Ni}\left(1,2-\mathrm{C}_{2} \mathrm{~B}_{9} \mathrm{H}_{10}\right)_{2}\right]^{-}$, we carried out quantum chemical calculations of the all synthesized complexes.

\subsection{Quantum Chemical Calculations}

The parent nickel(III) bis(dicarbollide) $\left[3,3^{\prime}-\mathrm{Ni}\left(1,2-\mathrm{C}_{2} \mathrm{~B}_{9} \mathrm{H}_{11}\right)_{2}\right]^{-}$is known to prefer the transoid configuration, while the gauche form is only slightly less $(\sim 1 \mathrm{kcal} / \mathrm{mol})$ preferred [7,41]. Our DFT calculations using the BP86 functional with cc-pvdz basis set gave the similar result with the transoid configuration preferred over the gauche one by only $0.4 \mathrm{kcal} / \mathrm{mol}$, whereas the cisoid-rotamer is energetically disfavored by as much as $4 \mathrm{kcal} / \mathrm{mol}$. These allow us to suppose that weak noncovalent intramolecular interactions could switch preferability of the transoid and gauche rotamers.

The transoid rotamer of the $\left[8,8^{\prime}-(\mathrm{MeS})_{2}-3,3^{\prime}-\mathrm{Ni}\left(1,2-\mathrm{C}_{2} \mathrm{~B}_{9} \mathrm{H}_{10}\right)_{2}\right]^{-}$isomer featuring four stabilizing $\mathrm{CH} \cdots \mathrm{S}$ hydrogen bonds $\left(\mathrm{r}(\mathrm{H} \cdots \mathrm{S})=2.72-2.74 \AA\right.$, $\mathrm{E}_{\mathrm{BCP}}=-1.8 \div-1.6 \mathrm{kcal} / \mathrm{mol}$, Figure 5) become unambiguously global minima preferred over the gauche rotamer by $3.7 / 4.0 \mathrm{kcal} / \mathrm{mol}\left(\Delta \mathrm{E} / \Delta \mathrm{G}_{298}\right.$ terms). The gauche rotamer is skewed to the $117.4^{\circ}$ from the standard value of $108^{\circ}$, in order to provide shorter and stronger $\mathrm{CH} \cdots \mathrm{S}$ bonds $\left(\mathrm{r}(\mathrm{H} \cdots \mathrm{S})=2.66 \AA, \mathrm{E}_{\mathrm{BCP}}=2.0 \mathrm{kcal} / \mathrm{mol}\right)$, but only two such bonds could form. The cisoid rotamer has only $S \ldots S$ stabilizing interaction, and this pushes it as high as $\Delta \mathrm{E}=+10.3 \mathrm{kcal} / \mathrm{mol}$ relative to the transoid one. 


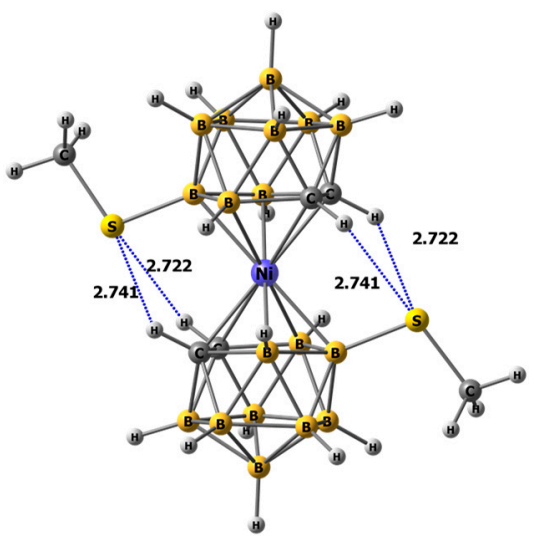

(a)

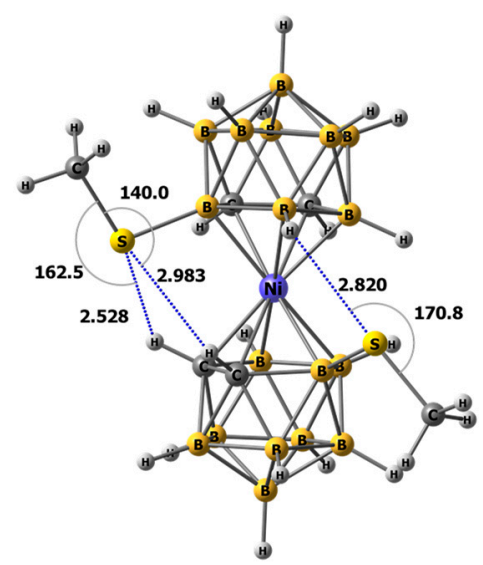

(b)

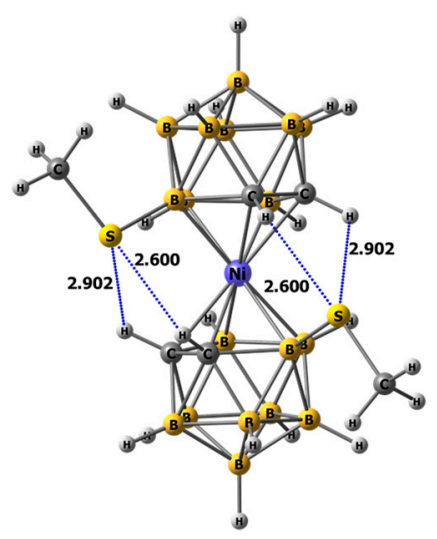

(c)

Figure 5. DFT-optimized structures of methylsulfanyl derivatives of nickel(III) bis(dicarbollide): (a) $\left[8,8^{\prime}-(\mathrm{MeS})_{2}-3,3^{\prime}-\mathrm{Ni}\left(1,2-\mathrm{C}_{2} \mathrm{~B}_{9} \mathrm{H}_{10}\right)_{2}\right]^{-}$isomer; (b) $\left[4,7^{\prime}-(\mathrm{MeS})_{2}-3,3^{\prime}-\mathrm{Ni}\left(1,2-\mathrm{C}_{2} \mathrm{~B}_{9} \mathrm{H}_{10}\right)_{2}\right]^{-}$isomer; and (c) $\left[4,4^{\prime}-(\mathrm{MeS})_{2}-3,3^{\prime}-\mathrm{Ni}\left(1,2-\mathrm{C}_{2} \mathrm{~B}_{9} \mathrm{H}_{10}\right)_{2}\right]^{-}$isomer.

For the $\left[4,7^{\prime}-(\mathrm{MeS})_{2}-3,3^{\prime}-\mathrm{Ni}\left(1,2-\mathrm{C}_{2} \mathrm{~B}_{9} \mathrm{H}_{10}\right)_{2}\right]^{-}$isomer, the transoid rotamer has two equal $\mathrm{BH} \cdots \mathrm{S}$ chalcogen bonds $\left(\mathrm{r}(\mathrm{H} \cdots \mathrm{S})=2.56 \AA\right.$, angle $\mathrm{C}^{\mathrm{Me}} \mathrm{S} \cdots \mathrm{H}=170.7^{\circ}, \mathrm{E}_{\mathrm{BCP}}=-2.5 \mathrm{kcal} / \mathrm{mol}$. Despite the possibility of the $\mathrm{CH} \cdots \mathrm{S}$ interactions in this rotamer, such a configuration was not found as a minimum. The gauche rotamer was found to be slightly preferred over the transoid one $\left(\Delta \mathrm{E}=0.4 ; \Delta \mathrm{G}_{298}=0.8 \mathrm{kcal} / \mathrm{mol}\right)$, and exactly this was revealed in the crystal. This rotamer is stabilized by two nonequivalent $\mathrm{CH} \cdots \mathrm{S}$ interactions $\left(\mathrm{r}(\mathrm{H} \cdots \mathrm{S})=2.53\right.$ and $2.98 \AA, \mathrm{E}_{\mathrm{BCP}}=-2.6$ and $\left.-1.1 \mathrm{kcal} / \mathrm{mol}\right)$ and one $\mathrm{BH} \cdots \mathrm{S}$ chalcogen bond $\left(\mathrm{r}(\mathrm{H} \cdots \mathrm{S})=2.82 \AA\right.$, angle $\mathrm{C}^{\mathrm{Me}} \mathrm{S} \cdots \mathrm{H}=170.8^{\circ}$, and $\mathrm{E}_{\mathrm{BCP}}=-1.4 \mathrm{kcal} / \mathrm{mol}$, Figure 5). The cisoid rotamer has $\mathrm{S} \cdots \mathrm{S}\left(\mathrm{r}(\mathrm{S} \cdots \mathrm{S})=3.53 \AA, \mathrm{E}_{\mathrm{BCP}}=-1.2 \mathrm{kcal} / \mathrm{mol}\right), \mathrm{CH} \cdots \mathrm{S}\left(\mathrm{r}(\mathrm{H} \cdots \mathrm{S})=2.60 \AA\right.$, and $\left.\mathrm{E}_{\mathrm{BCP}}=-3.0 \mathrm{kcal} / \mathrm{mol}\right)$, and $\mathrm{BH} \cdots \mathrm{S}\left(\mathrm{r}(\mathrm{H} \cdots \mathrm{S})=2.89 \AA\right.$ and $\left.\mathrm{E}_{\mathrm{BCP}}=-1.5 \mathrm{kcal} / \mathrm{mol}\right)$ interactions, but they are not enough to shift the energetic preference, leaving the cisoid rotamer to be $\Delta \mathrm{E}=+4.3 \mathrm{kcal} / \mathrm{mol}$ higher than the gauche one.

For the $\left[4,4^{\prime}-(\mathrm{MeS})_{2}-3,3^{\prime}-\mathrm{Ni}\left(1,2-\mathrm{C}_{2} \mathrm{~B}_{9} \mathrm{H}_{10}\right)_{2}\right]^{-}$isomer, the transoid rotamer should have two sulfur atoms close to each other. Despite the possibility of stabilizing $\mathrm{CH} \cdots \mathrm{S}$ interactions in this rotamer sulfur atoms repulsion leads to the mutual rotation of the dicarbollide ligands, pushing molecules to the gauche configuration. Thus, no transoid rotamer was found on the PES, but two gauche and two cisoid rotamers were found (due to molecular symmetry). At that, the most favored one is a gauche1 rotamer, which features four $\mathrm{CH} \cdots \mathrm{S}$ interactions $\left(\mathrm{r}(\mathrm{H} \cdots \mathrm{S})=2.60-2.90 \AA, \mathrm{E}_{\mathrm{BCP}}=-2.2 \div-1.3 \mathrm{kcal} / \mathrm{mol}\right.$,

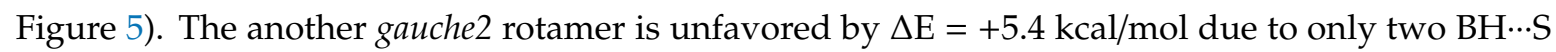
and $\mathrm{S} \cdots \mathrm{S}$ stabilizing interactions. Both the cisoid rotamers remain highly unfavorable $(\Delta \mathrm{E}=+8.2$ and $+6.0 \mathrm{kcal} / \mathrm{mol}$ ), despite the presence of four BH..S (cisoid1) and two BH...S with two CH..S (cisoid2) interactions. At that, the cisoid2 rotamer featuring $\mathrm{CH} \cdots \mathrm{S}$ interactions is slightly preferred.

In general, since $\mathrm{CH} \cdots \mathrm{S}$ hydrogen bonds are formed with lone pairs of sulfur atoms, the formation of two such interactions per sulfur atom in methylsulfanyl derivatives is allowed. This results in stabilization of gauche1-[4,4'-(MeS) $\left.)_{2}-3,3^{\prime}-\mathrm{Ni}\left(1,2-\mathrm{C}_{2} \mathrm{~B}_{9} \mathrm{H}_{10}\right)_{2}\right]^{-}$and transoid- $\left[8,8^{\prime}-(\mathrm{MeS})_{2}-3,3^{\prime}-\right.$ $\left.\mathrm{Ni}\left(1,2-\mathrm{C}_{2} \mathrm{~B}_{9} \mathrm{H}_{10}\right)_{2}\right]^{-}$rotamers. In contrast, only one intramolecular chalcogen bond can be effectively formed, since only one $\sigma$-hole in the extension of the $\mathrm{CH}_{3}-\mathrm{S}$ bond is pointed in the appropriate direction. The formation of the chalcogen bond with hydride ligand requires rotation of the SMe group to form a linear fragment of $\mathrm{C}-\mathrm{S} \cdots \mathrm{H}-\mathrm{B}$, which, in turn, leads to disruption of the $\mathrm{CH}^{\mathrm{Me}} \cdots \mathrm{HB}$ interactions. As a result, the transoid rotamer of the $4,7^{\prime}$ isomer with strongest chalcogen bonds have only two interactions of the Me group with $\mathrm{BH}$ (one per the Me group). Notable that the least favored among all conformers cisoid-rotamer of the 4,4'-isomer featuring four S...HB interactions has no interactions of the Me groups with the boron cage at all. Therefore, with a small difference in energy between gauche and transoid rotamers, the possibility of formation of four stabilizing $\mathrm{CH} \cdots \mathrm{S}$ interactions unambiguously leads to formation of the corresponding rotamer. Such a conformer is further stabilized due to a larger amount 
of $\mathrm{CH}^{\mathrm{Me}} \ldots \mathrm{HB}$ interactions. When the atomic configuration does not allow such interactions, chalcogen bonds affect the rotamer stabilization.

\section{Materials and Methods}

\subsection{General Considerations}

All reactions were performed in an inert nitrogen atmosphere while using standard Schlenk techniques. $\left(\mathrm{Bu}_{4} \mathrm{~N}\right)\left[10-\mathrm{MeS}-7,8-\mathrm{C}_{2} \mathrm{~B}_{9} \mathrm{H}_{11}\right],\left(\mathrm{Bu}_{4} \mathrm{~N}\right)\left[9-\mathrm{MeS}-7,8-\mathrm{C}_{2} \mathrm{~B}_{9} \mathrm{H}_{11}\right]$, and $\left[\mathrm{Ni}(\mathrm{acac})_{2}\right]_{3}$ were prepared as described in the literature [42-44]. Anhydrous tetrahydrofuran was prepared by using the standard procedure [45]. Acros Organics silica gel $(0.060-0.200 \mathrm{~mm})$ was used for column chromatography. Thin-layer chromatograms (DC Kieselgel $\mathrm{F}_{254}$ silica gel on aluminum plates, Merck) were visualized, using $0.1 \% \mathrm{PdCl}_{2}$ in $3 \mathrm{M}$ of $\mathrm{HCl}(\mathrm{aq})$. The ${ }^{11} \mathrm{~B} \mathrm{NMR}$ spectra at $128.4 \mathrm{MHz}$ were recorded with a Bruker Avance-400 spectrometer (Bruker Biospin AG, Fällanden, Switzerland) and referenced by using $\mathrm{BF}_{3} \cdot \mathrm{Et}_{2} \mathrm{O}$ as the external standard. High-resolution mass spectra (HRMS) were measured on a Bruker micrOTOF II instrument (Bruker Daltonics, Bremen, Germany), using electrospray ionization (ESI). The measurements were done in a negative ion mode $(3200 \mathrm{~V})$; mass range from m/z 50 to m/z 3000; external or internal calibration was done with ESI Tuning Mix, Agilent (Santa Clara, CA, USA). A syringe injection was used for solutions in acetonitrile (flow rate $3 \mathrm{~mL} / \mathrm{min}$ ). Nitrogen was applied as a dry gas; the interface temperature was set at $180^{\circ} \mathrm{C}$.

\subsection{Synthesis of Methylsulfanyl Derivatives of Nickel(III) Bis(Dicarbollide)}

\subsubsection{Synthesis of $\left(\mathrm{Bu}_{4} \mathrm{~N}\right)\left[8,8^{\prime}-(\mathrm{MeS})_{2}-3,3^{\prime}-\mathrm{Ni}\left(1,2-\mathrm{C}_{2} \mathrm{~B}_{9} \mathrm{H}_{10}\right)_{2}\right]$}

First, $0.25 \mathrm{~g}(2.20 \mathrm{mmol})$ of ${ }^{\mathrm{t}} \mathrm{BuOK}$ was added to solution of $0.41 \mathrm{~g}(1.11 \mathrm{mmol})$ of $\left(\mathrm{Bu}_{4} \mathrm{~N}\right)\left[10-\mathrm{MeS}-7,8-\mathrm{C}_{2} \mathrm{~B}_{9} \mathrm{H}_{11}\right]$ in $40 \mathrm{~mL}$ of THF and heated under reflux for $40 \mathrm{~min}$. Then, $0.21 \mathrm{~g}$ $(0.28 \mathrm{mmol})$ of $\left[\mathrm{Ni}(\mathrm{acac})_{2}\right]_{3}$ was added, and the reaction mixture was heated under reflux for $24 \mathrm{~h}$. The reaction mixture was allowed to cool to room temperature and concentrated to dryness in vacuo. The residue was treated with $50 \mathrm{~mL}$ of dichloromethane and $50 \mathrm{~mL}$ of water. Organic layer was separated, dried over $\mathrm{Na}_{2} \mathrm{SO}_{4}$, filtered, and evaporated in vacuo. The crude product was purified by column chromatography on silica, using dichloromethane as eluent to obtain $0.20 \mathrm{~g}(55 \%)$ of brown product. ${ }^{11} \mathrm{~B}$ NMR (acetone- $d_{6}, \mathrm{ppm}$ ): $\delta=19.6,9.8,-119.8$. HRMS (ESI): calcd. for $\mathrm{C}_{6} \mathrm{~B}_{18} \mathrm{H}_{26} \mathrm{NiS}_{2}[\mathrm{M}]^{-} 415.2630$; found 415.2621

3.2.2. Synthesis of $\left(\mathrm{Bu}_{4} \mathrm{~N}\right)\left[4,4^{\prime}-(\mathrm{MeS})_{2}-3,3^{\prime}-\mathrm{Ni}\left(1,2-\mathrm{C}_{2} \mathrm{~B}_{9} \mathrm{H}_{10}\right)_{2}\right]$ (rac-isomer) and $\left(\mathrm{Bu}_{4} \mathrm{~N}\right)\left[4,7^{\prime}-(\mathrm{MeS})_{2}-3,3^{\prime}-\right.$ $\left.\mathrm{Ni}\left(1,2-\mathrm{C}_{2} \mathrm{~B}_{9} \mathrm{H}_{10}\right)_{2}\right]$ (meso-isomer)

First, $0.59 \mathrm{~g}(5.21 \mathrm{mmol})$ of ${ }^{\mathrm{t}} \mathrm{BuOK}$ was added to a solution of $1.10 \mathrm{~g}(2.61 \mathrm{mmol})$ of $\left(\mathrm{Bu}_{4} \mathrm{~N}\right)\left[9-\mathrm{MeS}-7,8-\mathrm{C}_{2} \mathrm{~B}_{9} \mathrm{H}_{11}\right]$ in $40 \mathrm{~mL}$ of THF and heated under reflux for $40 \mathrm{~min}$. Then, $0.50 \mathrm{~g}$ $(0.65 \mathrm{mmol})$ of $\left[\mathrm{Ni}(\mathrm{acac})_{2}\right]_{3}$ was added, and the reaction mixture was heated under reflux for $24 \mathrm{~h}$. The reaction mixture was allowed to cool to room temperature and concentrated to dryness in vacuo. The residue was treated with $50 \mathrm{~mL}$ of dichloromethane and $50 \mathrm{~mL}$ of water. The organic layer was separated, washed over $\mathrm{Na}_{2} \mathrm{SO}_{4}$, filtered, and evaporated in vacuo. The mixture of isomers was separated by column chromatography on silica with the mixture of dichloromethane and chloroform $(4: 1, \mathrm{v} / \mathrm{v})$ as eluent to obtain $0.26 \mathrm{~g}\left(30 \%, \mathrm{R}_{\mathrm{f}}=0.75\right)$ of $\mathrm{rac}$-isomer and $0.21 \mathrm{~g}\left(24 \%, \mathrm{R}_{\mathrm{f}}=0.50\right)$ of meso-isomer as brown solids. Rac-isomer: ${ }^{11} \mathrm{~B}$ NMR (acetone- $d_{6}, \mathrm{ppm}$ ): $\delta=69.8,6.3,-1.4,-38.9$, -74.3. HRMS (ESI): calcd. for $\mathrm{C}_{6} \mathrm{~B}_{18} \mathrm{H}_{26} \mathrm{NiS}_{2}[\mathrm{M}]^{-}$415.2630; found 415.2625. meso-isomer: ${ }^{11} \mathrm{~B} \mathrm{NMR}$ (acetone- $d_{6}, \mathrm{ppm}$ ): $\delta=52.2,6.8,-26.7,-37.8,-42.0$. HRMS (ESI): calcd. for $\mathrm{C}_{6} \mathrm{~B}_{18} \mathrm{H}_{26} \mathrm{NiS}_{2}[\mathrm{M}]^{-}$ 415.2630; found 415.2624. 


\subsection{X-Ray Diffraction Study}

X-ray experiments for compounds $\left(\mathrm{Bu}_{4} \mathrm{~N}\right)\left[8,8^{\prime}-(\mathrm{MeS})_{2}-3,3^{\prime}-\mathrm{Ni}\left(1,2-\mathrm{C}_{2} \mathrm{~B}_{9} \mathrm{H}_{10}\right)_{2}\right]$ and $\left(\mathrm{Bu}_{4} \mathrm{~N}\right)\left[4,7^{\prime}-\right.$ $\left.(\mathrm{MeS})_{2}-3,3^{\prime}-\mathrm{Ni}\left(1,2-\mathrm{C}_{2} \mathrm{~B}_{9} \mathrm{H}_{10}\right)_{2}\right]$ were carried out by using SMART APEX2 CCD diffractometer $(\lambda(\mathrm{Mo}-\mathrm{K} \alpha)$ $=0.71073 \AA$, graphite monochromator, $\omega$-scans) at $120 \mathrm{~K}$. Collected data were processed by the SAINT and SADABS programs incorporated into the APEX2 program package [46]. The structures were solved by the direct methods and refined by the full-matrix least-squares procedure against F2 in anisotropic approximation. The refinement was carried out with the SHELXTL program [47]. In the case of $\left(\mathrm{Bu}_{4} \mathrm{~N}\right)\left[8,8^{\prime}-(\mathrm{MeS})_{2}-3,3^{\prime}-\mathrm{Ni}\left(1,2-\mathrm{C}_{2} \mathrm{~B}_{9} \mathrm{H}_{10}\right)_{2}\right]$, all carborane hydrogen atoms were refined isotropically, without constraints. In contrast, reflection ability of $\left(\mathrm{Bu}_{4} \mathrm{~N}\right)\left[8,8^{\prime}-(\mathrm{MeS})_{2}-3,3^{\prime}-\mathrm{Ni}(1,2-\right.$ $\left.\mathrm{C}_{2} \mathrm{~B}_{9} \mathrm{H}_{10}\right)_{2}$ ] was extremely weak; therefore, all hydrogen atoms were refined within the riding model. The details of data collection and crystal structures refinement are summarized in Table S1. CCDC numbers (No.1966075 for $\left(\mathrm{Bu}_{4} \mathrm{~N}\right)\left[8,8^{\prime}-(\mathrm{MeS})_{2}-3,3^{\prime}-\mathrm{Ni}\left(1,2-\mathrm{C}_{2} \mathrm{~B}_{9} \mathrm{H}_{10}\right)_{2}\right]$ and No.1966074 for $\left(\mathrm{Bu}_{4} \mathrm{~N}\right)\left[4,7^{\prime}-\right.$ $\left.\left.(\mathrm{MeS})_{2}-3,3^{\prime}-\mathrm{Ni}\left(1,2-\mathrm{C}_{2} \mathrm{~B}_{9} \mathrm{H}_{10}\right)_{2}\right]\right)$ contain the supplementary crystallographic data for this paper. These data can be obtained free of charge via www.ccdc.cam.ac.uk/data_request/cif.

\subsection{Quantum Chemical Calculations}

The geometry optimizations were performed with the BP86 functional $[48,49]$ with cc-pvdz basis set [50-53], without any symmetry restrictions, using Gaussain09 [54]. The tight SCF convergence criteria and ultrafine grid were applied. All minima on the PES were confirmed to have no negative values in their diagonalized force constants matrix. The QTAIM analysis was performed by using the AIMALL [55] and MULTIWFN [56] programs package based on the wave function obtained by the BP86 calculations. The energies of noncovalent intramolecular interactions were calculated by using the correlation between the interaction energy $\left(\mathrm{E}_{\mathrm{BCP}}\right)$ and the value of the potential energy density function $\mathrm{V}_{\mathrm{C}}(\mathrm{r})$ at the corresponding critical point $(3,-1)$ : $\mathrm{E}_{\mathrm{BCP}}=0.5 \cdot \mathrm{V}_{\mathrm{C}}(\mathrm{r})$ (Table S2) $[57,58]$. Such approach is widely used for energetic analysis of intermolecular interactions of different types $[42,43,59,60]$.

\section{Conclusions}

Symmetrically and unsymmetrically substituted methylsulfanyl derivatives of nickel(III) bis(dicarbollide) $\left(\mathrm{Bu}_{4} \mathrm{~N}\right)\left[8,8^{\prime}-(\mathrm{MeS})_{2}-3,3^{\prime}-\mathrm{Ni}\left(1,2-\mathrm{C}_{2} \mathrm{~B}_{9} \mathrm{H}_{10}\right)_{2}\right],\left(\mathrm{Bu}_{4} \mathrm{~N}\right)\left[4,4^{\prime}-(\mathrm{MeS})_{2}-3,3^{\prime}-\mathrm{Ni}\left(1,2-\mathrm{C}_{2} \mathrm{~B}_{9} \mathrm{H}_{10}\right)_{2}\right]$, and $\left(\mathrm{Bu}_{4} \mathrm{~N}\right)\left[4,7^{\prime}-(\mathrm{MeS})_{2}-3,3^{\prime}-\mathrm{Ni}\left(1,2-\mathrm{C}_{2} \mathrm{~B}_{9} \mathrm{H}_{10}\right)_{2}\right]$ were synthesized, starting from $\left[\mathrm{Ni}(\mathrm{acac})_{2}\right]_{3}$ and the corresponding methylsulfanyl derivatives of nido-carborane $\left(\mathrm{Bu}_{4} \mathrm{~N}\right)\left[10-\mathrm{MeS}-7,8-\mathrm{C}_{2} \mathrm{~B}_{9} \mathrm{H}_{11}\right]$ and $\left(\mathrm{Bu}_{4} \mathrm{~N}\right)\left[10-\mathrm{MeS}-7,8-\mathrm{C}_{2} \mathrm{~B}_{9} \mathrm{H}_{11}\right]$. Structures of the synthesized metallacarboranes were studied by single-crystal $X$-ray diffraction and quantum chemical calculations. The symmetrically substituted $8,8^{\prime}$-isomer was found to adopt transoid conformation stabilized by two pairs of intramolecular C-H...S hydrogen bonds between the dicarbollide ligands. The unsymmetrically substituted 4,7'-isomer adopts gauche conformation, which is stabilized by two nonequivalent $\mathrm{C}-\mathrm{H}$-.S hydrogen bonds and one short chalcogen B-H..S bond ( $2.53 \AA,-1.4 \mathrm{kcal} / \mathrm{mol})$. The gauche conformation stabilized by two pairs of C-H...S hydrogen bonds was found to be also preferred for the $4,7^{\prime}$-isomer. At a small difference in energy between the gauche and transoid rotamers, the possibility of formation of four stabilizing $\mathrm{CH} \cdots \mathrm{S}$ interactions unambiguously leads to the formation of the corresponding rotamers. When the atomic configuration does not allow such interactions, the formation of $\mathrm{BH} \cdots \mathrm{S}$ chalcogen bonds affects the rotamer stabilization.

Supplementary Materials: The following are available online at http://www.mdpi.com/1420-3049/24/24/4449/s1.

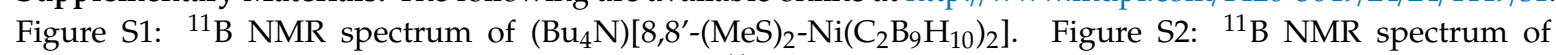
$\left(\mathrm{Bu}_{4} \mathrm{~N}\right)\left[4,4^{\prime}-(\mathrm{MeS})_{2}-\mathrm{Ni}\left(\mathrm{C}_{2} \mathrm{~B}_{9} \mathrm{H}_{10}\right)_{2}\right]$. Figure S3: ${ }^{11} \mathrm{~B}$ NMR spectrum of $\left(\mathrm{Bu}_{4} \mathrm{~N}\right)\left[4,7^{\prime}-(\mathrm{MeS})_{2}-\mathrm{Ni}\left(\mathrm{C}_{2} \mathrm{~B}_{9} \mathrm{H}_{10}\right)_{2}\right]$. Figure S4: Crystal packing fragment of $\left(\mathrm{Bu}_{4} \mathrm{~N}\right)\left[8,8^{\prime}-(\mathrm{MeS})_{2}-3,3^{\prime}-\mathrm{Ni}\left(1,2-\mathrm{C}_{2} \mathrm{~B}_{9} \mathrm{H}_{10}\right)_{2}\right]$. Figure S5: Crystal packing fragment of $\left(\mathrm{Bu}_{4} \mathrm{~N}\right)\left[4,7^{\prime}-(\mathrm{MeS})_{2}-3,3^{\prime}-\mathrm{Ni}\left(1,2-\mathrm{C}_{2} \mathrm{~B}_{9} \mathrm{H}_{10}\right)_{2}\right]$. Table S1: Crystallographic data for compounds $\left(\mathrm{Bu}_{4} \mathrm{~N}\right)\left[8,8^{\prime}-(\mathrm{MeS})_{2}-3,3^{\prime}-\mathrm{Ni}\left(1,2-\mathrm{C}_{2} \mathrm{~B}_{9} \mathrm{H}_{10}\right)_{2}\right]$ and $\left(\mathrm{Bu}_{4} \mathrm{~N}\right)\left[4,7^{\prime}-(\mathrm{MeS})_{2}-3,3^{\prime}-\mathrm{Ni}\left(1,2-\mathrm{C}_{2} \mathrm{~B}_{9} \mathrm{H}_{10}\right)_{2}\right]$. Table S2: Characteristics of $(3,-1)$ bond critical points associated with the intramolecular interactions of SMe group title. 
Author Contributions: S.A.A., synthesis of nickel bis(dicarbollide) derivatives; K.Y.S., single-crystal X-ray diffraction study; O.A.F., quantum chemical calculations; I.B.S., experiment planning, data analysis, and manuscript conception. All authors were involved in preparation of the manuscript.

Funding: This work was supported by the Russian Science Foundation (Grant No. 16-13-10331).

Acknowledgments: The single-crystal X-ray diffraction data were obtained by using equipment from the Center for Molecular Structure Studies at A.N. Nesmeyanov Institute of Organoelement Compounds, operating with support from the Ministry of Science and Higher Education of the Russian Federation.

Conflicts of Interest: The authors declare no conflicts of interest.

\section{References}

1. Feringa, B.L.; Browne, W.R. Molecular Switches, 2nd ed.; Wiley-VCH: Weinheim, Germany, 2011; 792p.

2. Karnati, C.; Ji, H.-F. Molecular logic gates. In Micromanufacturing and Nanotechnology; Mahalik, N.P., Ed.; Springer-Verlag: Berlin, Germany, 2006; 468p.

3. Katz, E. (Ed.) Molecular and Supramolecular Information Processing. From Molecular Switches to Logic. Systems; Wiley-VCH: Weinheim, Germany, 2012; 364p.

4. de Silva, A.P. Molecular Logic.-based Computation; RSC Publishing: Cambridge, UK, 2013; 398p.

5. Andreasson, I.; Pischel, U. Molecules with a Sense of Logic: A Progress report. Chem. Soc. Rev. 2015, 44, 1053-1069. [CrossRef] [PubMed]

6. Erbas-Cakmak, S.; Kolemen, S.; Sedgwick, A.C.; Gunnlaugsson, T.; James, T.D.; Yoon, J.; Akkaya, E.U. Molecular Logic Gates: The Past, Present and Future. Chem. Soc. Rev. 2018, 47, 2228-2248. [CrossRef] [PubMed]

7. Hawthorne, M.F.; Zink, J.I.; Skelton, J.M.; Bayer, M.B.; Liu, C.; Livshits, E.; Baer, R.; Neuhauser, D. Electrical or Photocontrol of the Rotary Motion of a Metallacarborane. Science 2004, 303, 1849-1852. [CrossRef] [PubMed]

8. Hawthorne, M.F.; Ramachandran, B.M.; Kennedy, R.D.; Knobler, C.B. Approaches to Rotary Molecular Motors. Pure Appl. Chem. 2006, 78, 1299-1304. [CrossRef]

9. Sivaev, I.B.; Bregadze, V.I. Chemistry of Nickel and Iron Bis(dicarbollides). A Review. J. Organomet. Chem. 2000, 614-615, 27-36. [CrossRef]

10. Bühl, M.; Holub, J.; Hnyk, D.; Macháček, J. Computational Studies of Structures and Properties of Metallaboranes. 2. Transition-Metal Dicarbollide Complexes. Organometallics 2006, 25, 2173-2181. [CrossRef]

11. Safronov, A.V.; Shlyakhtina, N.I.; Everett, T.A.; VanGordon, M.R.; Sevryugina, Y.V.; Jalisatgi, S.S.; Hawthorne, M.F. Direct Observation of Bis(dicarbollyl)nickel Conformers in Solution by Fluorescence Spectroscopy: An Approach to Redox-Controlled Metallacarborane Molecular Motors. Inorg. Chem. 2014, 53, 10045-10053. [CrossRef]

12. Shlyakhtina, N.I.; Safronov, A.V.; Sevryugina, Y.V.; Jalisatgi, S.S.; Hawthorne, M.F. Synthesis, Characterization, and Preliminary Fluorescence Study of a Mixed Ligand Bis(dicarbollyl)nickel Complex bearing a Tryptophan-BODIPY FRET Couple. J. Organomet. Chem. 2015, 798, 234-244. [CrossRef]

13. Warren, L.F.; Hawthorne, M.F. Chemistry of the Bis[ $\pi$.-(3)-1,2-dicarbollyl] Metalates of Nickel and Palladium. J. Am. Chem. Soc. 1970, 92, 1157-1173. [CrossRef]

14. Andreichuk, E.P.; Anisimov, A.A.; Shmalko, A.V.; Suponitsky, K.Y.; Sivaev, I.B.; Bregadze, V.I. Stability of Nickel Bis(dicarbollide) Complexes. Mendeleev Commun. 2019, 29, 534-536. [CrossRef]

15. Sivaev, I.B. Ferrocene and Transition Metal Bis(dicarbollides) as Platform for Design of Rotatory Molecular Switches. Molecules 2017, 22, 2201. [CrossRef] [PubMed]

16. Bühl, M.; Hnyk, D.; Macháček, J. Computational Study of Structures and Properties of Metallaboranes: Cobalt Bis(dicarbollide). Chem. Eur. J. 2005, 11, 4109-4120. [CrossRef] [PubMed]

17. Zaulet, A.; Teixidor, F.; Bauduin, P.; Diat, O.; Hirva, P.; Ofori, A.; Viñas, C. Deciphering the Role of the Cation in Anionic Cobaltabisdicarbollide Clusters. J. Organomet. Chem. 2018, 865, 214-225. [CrossRef]

18. Anufriev, S.A.; Erokhina, S.A.; Suponitsky, K.Y.; Godovikov, I.A.; Filippov, O.A.; Fabrizi de Biani, F.; Corsini, M.; Chizhov, A.O.; Sivaev, I.B. Methylsulfanyl-Stabilized Rotamers of Cobalt Bis(dicarbollide). Eur. J. Inorg. Chem. 2017, 38-39, 4444-4451. [CrossRef]

19. Anufriev, S.A.; Erokhina, S.A.; Suponitsky, K.Y.; Anisimov, A.A.; Laskova, J.N.; Godovikov, I.A.; Fabrizi de Biani, F.; Corsini, M.; Sivaev, I.B.; Bregadze, V.I. Synthesis and Structure of Bis(methylsulfanyl) Derivatives of Iron Bis(dicarbollide). J. Organomet. Chem. 2018, 865, 239-246. [CrossRef] 
20. Timofeev, S.V.; Anufriev, S.A.; Sivaev, I.B.; Bregadze, V.I. Synthesis of Cobalt Bis(8-methylthio-1,2-Dicarbollide)-Pentacarbonyltungsten Complexes. Russ. Chem. Bull. 2018, 67, 570-572. [CrossRef]

21. Sivaev, I.B. Intramolecular Non-Covalent Interactions in Carboranes and Metallacarboranes. In Proceedings of the 8th European Conference on Boron Chemistry (EUROBORON-8), Montpellier, France, 24-27 June 2019. KL2.

22. Hawthorne, M.F.; Young, D.C.; Andrews, T.D.; Howe, D.V.; Pilling, R.L.; Pitts, A.D.; Reintjes, M.; Warren, L.F.; Wegner, P.A. $\pi$-Dicarbollyl Derivatives of the Transition Metals. Metallocene Analogs. J. Am. Chem. Soc. 1968, 90, 879-896. [CrossRef]

23. Spokoyny, A.M.; Li, T.C.; Farha, O.K.; Machan, C.W.; She, C.; Stern, C.L.; Marks, T.J.; Hupp, J.T.; Mirkin, C.A. Electronic Tuning of Nickel-Based Bis(dicarbollide) Redox Shuttles in Dye-Sensitized Solar Cells. Angew. Chem. Int. Ed. 2010, 49, 5339-5343. [CrossRef]

24. Shmal'ko, A.V.; Anufriev, S.A.; Anisimov, A.A.; Stogniy, M.Y.; Sivaev, I.B.; Bregadze, V.I. Synthesis of Cobalt and Nickel 6,6'-Diphenyl Bis(dicarbollides). Russ. Chem. Bull. 2019, 68, 1239-1247. [CrossRef]

25. Kennedy, R.D.; Knobler, C.B.; Hawthorne, M.F. Toward Unidirectional Motion in Nickelacarboranes: Characterization of Diastereomeric Nickel Bis(dicarbollide) Complexes Derived from the [nido-7- $\left.\mathrm{CH}_{3}-7,8-\mathrm{C}_{2} \mathrm{~B}_{9} \mathrm{H}_{11}\right]^{-}$Anion. Inorg. Chem. 2009, 48, 9377-9384. [CrossRef]

26. Pennanen, T.O.; Macháček, J.; Taubert, S.; Vaara, J.; Hnyk, D. Ferrocene-Like Iron Bis(dicarbollide), $\left[3-\mathrm{Fe}^{\mathrm{III}}-\left(1,2-\mathrm{C}_{2} \mathrm{~B}_{9} \mathrm{H}_{11}\right)_{2}\right]^{-}$. The First Experimental and Theoretical Refinement of a Paramagnetic ${ }^{11} \mathrm{~B}$ NMR Spectrum. Phys. Chem. Chem. Phys. 2010, 12, 7018-7025. [CrossRef] [PubMed]

27. Stogniy, M.Y.; Erokhina, S.A.; Kosenko, I.D.; Semioshkin, A.A.; Sivaev, I.B. Dimethyloxonium and Methoxy Derivatives of nido-Carborane and Metal Complexes Thereof. Inorganics 2019, 7, 46. [CrossRef]

28. Petřiček, V.; Maly, K.; Petřina, A.; Baše, K.; Linek, A. The Crystal and Molecular Structure of $\left(s-1,4^{\prime}, 2,1^{\prime}\right)-$ 3,3'-commo-Bis [8-Methoxy-1,2-Dicarba-3-Nickela-closo-Dodecaborane(11)], [8- $\left.\mathrm{CH}_{3} \mathrm{O}-1,2-\mathrm{C}_{2} \mathrm{~B}_{9} \mathrm{H}_{10}\right]_{2} \mathrm{Ni}$. Z. Kristallogr. 1984, 166, 1-10. [CrossRef]

29. Nuñez, R.; Tutusaus, O.; Teixidor, F.; Viñas, C.; Sillanpää, R.; Kivekäs, R. Highly Stable Neutral and Positively Charged Dicarbollide Sandwich Complexes. Chem. Eur. J. 2005, 11, 5637-5647. [CrossRef]

30. Stogniy, M.Y.; Erokhina, S.A.; Anisimov, A.A.; Suponitsky, K.Y.; Sivaev, I.B.; Bregadze, V.I. 10$\mathrm{NCCH}_{2} \mathrm{CH}_{2} \mathrm{OCH}_{2} \mathrm{CH}_{2} \mathrm{C} \equiv \mathrm{N}-7,8-\mathrm{C}_{2} \mathrm{~B}_{9} \mathrm{H}_{11}$ : Synthesis and Reactions with Various Nucleophiles. Polyhedron 2019, 174, 114170. [CrossRef]

31. Sheremetev, A.B.; Palysaeva, N.V.; Struchkova, M.I.; Suponitsky, K.Y.; Antipin, M.Y. Copper-Catalyzed C-N Coupling Reactions of Nitrogen-Rich Compounds-Reaction of Iodofurazans with s-Tetrazinylamines. Eur. J. Org. Chem. 2012, 2266-2272. [CrossRef]

32. Suponitsky, K.Y.; Lyssenko, K.A.; Ananyev, I.V.; Kozeev, A.M.; Sheremetev, A.B. Role of Weak Intermolecular Interactions in the Crystal Structure of

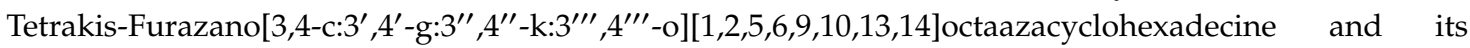
Solvates. Cryst. Growth Des. 2014, 14, 4439-4449. [CrossRef]

33. Database of Ionic Radii, Imperial College, London. Available online: http://abulafia.mt.ic.ac.uk/shannon/ ptable.php (accessed on 15 November 2019).

34. Murray, J.S.; Lane, P.; Politzer, P. Expansion of the $\sigma$-Hole Concept. J. Mol. Model. 2009, 15, $723-729$. [CrossRef]

35. Mahmudov, K.T.; Kopylovich, M.N.; da Silva, M.F.C.G.; Pombeiro, A.J.L. Chalcogen Bonding in Synthesis, Catalysis and Design of Materials. Dalton Trans. 2017, 46, 10121-10138. [CrossRef]

36. Scilabra, P.; Terraneo, G.; Resnati, G. The Chalcogen Bond in Crystalline Solids: A World Parallel to Halogen Bond. Acc. Chem. Res. 2019, 52, 1313-1324. [CrossRef]

37. Aakeroy, C.B.; Bryce, D.L.; Desiraju, G.R.; Frontera, A.; Legon, A.C.; Nicotra, F.; Rissanen, K.; Scheiner, S.; Terraneo, G.; Metrangolo, P.; et al. Definition of the Chalcogen Bond (IUPAC Recommendations 2019). Pure Appl. Chem. 2019, 91, 1889-1892. [CrossRef]

38. Fanfrlík, J.; Hnyk, D.; Hobza, P. Chalcogen Bonding due to the Exo-Substitution of Icosahedral Dicarbaborane. Molecules 2019, 24, 2657. [CrossRef] [PubMed]

39. Esrafili, M.D.; Mohammadian-Sabet, F.; Baneshi, M.M. An ab Initio Investigation of Chalcogen-Hydride Interactions Involving $\mathrm{HXeH}$ as a Chalcogen Bond Acceptor. Struct. Chem. 2016, 27, 785-792. [CrossRef] 
40. Sahoo, D.K.; Jena, S.; Dutta, J.; Rana, A.; Biswal, H.S. Nature and Strength of M-H...S and M-H $\cdots$ Se (M = Mn, $\mathrm{Fe}$, \& Co) Hydrogen Bond. J. Phys. Chem. A 2019, 123, 2227-2236. [CrossRef]

41. Ma, N.-N.; Li, S.-J.; Yan, L.-K.; Qiu, Y.-Q.; Su, Z.-M. Switchable NLO Response Induced by Rotation of Metallacarboranes $\left[\mathrm{Ni}^{\mathrm{III} / \mathrm{IV}}\left(\mathrm{C}_{2} \mathrm{~B}_{9} \mathrm{H}_{11}\right)_{2}\right]^{-/ 0}$ and C-,B-Functionalized Derivatives. Dalton Trans. 2014, 43, 5069-5075. [CrossRef]

42. Anufriev, S.A.; Sivaev, I.B.; Suponitsky, K.Y.; Bregadze, V.I. Practical Synthesis of 9-Methylthio-7,8-nido-Carborane [9-MeS-7,8- $\left.\mathrm{C}_{2} \mathrm{~B}_{9} \mathrm{H}_{11}\right]^{-}$. Some Evidences of $\mathrm{BH} \cdots \times$ X Hydride-Halogen Bonds in 9- $\mathrm{XCH}_{2}(\mathrm{Me}) \mathrm{S}-7,8-\mathrm{C}_{2} \mathrm{~B}_{9} \mathrm{H}_{11}(\mathrm{X}=\mathrm{Cl}, \mathrm{Br}, \mathrm{I})$. J. Organomet. Chem. 2017, 849-850, 315-323. [CrossRef]

43. Anufriev, S.A.; Sivaev, I.B.; Suponitsky, K.Y.; Godovikov, I.A.; Bregadze, V.I. Synthesis of 10-Methylsulfide and 10-Alkylmethylsulfonium nido-Carborane Derivatives: B-H $\cdots \pi$ Interactions between the B-H-B Hydrogen Atom and Alkyne Group in 10-RC $\equiv \mathrm{CCH}_{2} \mathrm{~S}(\mathrm{Me})-7,8-\mathrm{C}_{2} \mathrm{~B}_{9} \mathrm{H}_{11}$. Eur. J. Inorg. Chem. 2017, 38-39, 4436-4443. [CrossRef]

44. Wielandt, J.W.; Ruckerbauer, D. Hexakis(acetylacetonato)trinickel(II). Inorg. Synth. 2010, 35, 121-122. [CrossRef]

45. Armarego, W.L.F.; Chai, C.L.L. Purification of Laboratory Chemicals; Butterworth-Heinemann: Burlington, MA, USA, 2009; 790p.

46. APEX2 and SAINT; Bruker AXS Inc.: Madison, WI, USA, 2014.

47. Sheldrick, G.M. Crystal Structure Refinement with SHELXL. Acta Cryst. 2015, 71, 3-8. [CrossRef]

48. Perdew, J.P. Density-Functional Approximation for the Correlation-Energy of the Inhomogeneous Electron-Gas. Phys. Rev. B Condens. Matter 1986, 33, 8822-8824. [CrossRef]

49. Becke, A.D. Density-Functional Exchange-Energy Approximation with Correct Asymptotic-Behavior. Phys Rev. A 1988, 38, 3098-3100. [CrossRef] [PubMed]

50. Dunning, T.H. Gaussian-Basis Sets for Use in Correlated Molecular Calculations. 1. The Atoms Boron through Neon and Hydrogen. J. Chem. Phys. 1989, 90, 1007-1023. [CrossRef]

51. Woon, D.E.; Dunning, T.H. Gaussian-Basis Sets for Use in Correlated Molecular Calculations. 3. The Atoms Aluminum through Argon. J. Chem. Phys. 1993, 98, 1358-1371. [CrossRef]

52. Balabanov, N.B.; Peterson, K.A. Systematically Convergent Basis Sets for Transition Metals. I. All-Electron Correlation Consistent Basis Sets for the 3d Elements Sc-Zn. J. Chem. Phys. 2005, 123, 064107. [CrossRef]

53. Balabanov, N.B.; Peterson, K.A. Basis Set Limit Electronic Excitation Energies, Ionization Potentials, and Electron Affinities for the 3d Transition Metal Atoms: Coupled Cluster and Multireference Methods. J. Chem. Phys. 2006, 125, 074110. [CrossRef]

54. Frisch, M.J.; Trucks, G.W.; Schlegel, H.B.; Scuseria, G.E.; Robb, M.A.; Cheeseman, J.R.; Scalmani, G.; Barone, V.; Mennucci, B.; Petersson, G.A.; et al. Gaussian 09; Gaussian, Inc.: Wallingford, CT, USA, 2009.

55. Keith, T.A. AIMAll (Version 15.05.18); TK Gristmill Software: Overland Park, KS, USA, 2015.

56. Lu, T.; Chen, F. Multiwfn: A Multifunctional Wavefunction Analyzer. J. Comput Chem 2012, 33, 580-592. [CrossRef]

57. Espinosa, E.; Alkorta, I.; Rozas, I.; Elguero, J.; Molins, E. About the Evaluation of the Local Kinetic, Potential and Total Energy Densities in Closed-Shell Interactions. Chem. Phys. Lett. 2001, 336, 457-461. [CrossRef]

58. Espinosa, E.; Molins, E.; Lecomte, C. Hydrogen Bond Strengths Revealed by Topological Analyses of Experimentally Observed Electron Densities. Chem. Phys. Lett. 1998, 285, 170-173. [CrossRef]

59. Dmitrienko, A.O.; Karnoukhova, V.A.; Potemkin, A.A.; Struchkova, M.I.; Kryazhevskikh, I.A.; Suponitsky, K.Y. The Influence of Halogen type on Structural Features of Compounds Containing $\alpha$-Halo- $\alpha$, $\alpha$-Dinitroethyl Moieties. Chem. Heterocycl. Comp. 2017, 53, 532-539. [CrossRef]

60. Suponitsky, K.Y.; Burakov, N.I.; Kanibolotsky, A.L.; Mikhailov, V.A. Multiple Noncovalent Bonding in Halogen Complexes with Oxygen Organics. I. Tertiary Amides. J. Phys. Chem. A. 2016, 120, 4179-4190. [CrossRef]

Sample Availability: Samples of the compounds are not available from the authors. 